\title{
Representation of Muslim Groups in the United States on the Houston Chronicle and LA Times during the 2016 Presidential Election
}

\author{
Aldila Annisa Cahyaningtyas ${ }^{1}$, Ully D. Putri ${ }^{2}$, Bayu Kristianto ${ }^{3}$, Irid Farida Agoes ${ }^{4}$ \\ \{aldila.cahyaningtyas@gmail.com ${ }^{1}$, udputri@hotmail.com ${ }^{2}$, bayubaladewa@yahoo.com ${ }^{3}$, \\ irid.agoes@gmail.com ${ }^{4}$ \} \\ 1,2,3,4 American Studies, School of Strategic and Global Studies, Universitas Indonesia
}

\begin{abstract}
In news reporting, the media may have a positive, negative, or neutral picture of an issue. Typically, the picture is already painted based on their respective alignment. One of the factors determining a media alignment is the media's political affiliation. This study focuses on the media coverage of Muslim groups in two major U.S. newspapers, with both having opposite political affiliations. The Houston Chronicle is a conservative daily newspaper, while the LA Times is a liberal one. An analysis is conducted on articles published by these newspapers from January 1 to November 8, 2016. After a selection process, five opinion and editorial pieces are chosen from each and analyzed using the framing model of Zhongdang Pan and Kosicki. The result suggests that, unlike the initial assumption that in principle a conservative media would portray Muslim groups in a simplistic way by presenting negative reports, the representation of Muslim groups during the U.S. 2016 presidential election in the U.S. media is more complex.
\end{abstract}

Keywords: Muslim, representation, framing analysis, newspaper, print media

\section{Introduction}

This paper focuses on the influence of political affiliation on media alignment. The mass media have a very important position in the society, as seen from their many roles including as a means of communication for delivering information, be it a message or an idea. With mass media, people have easy access to all forms of information. Denis Mc Quail in [30] wrote that the mass media in general served various functions for the audience, i.e. as a source of information and interpretation that helped people understand the meaning of the information; as a means of agreement formation; as a platform for people to respond to ongoing issues in their environment; and as a means of transmitting cultural heritage and expressing cultural values and symbols needed to preserve community identity and sustainability [30]. Based on Mc Quails' statement, both print and electronic mass media are a very effective tool of information. Especially with the advance of technology, mass media - electronic media in particular - have a great power of influencing and shaping public opinions according to the messages of the articles they publish.

To perform function as a distributor of information, different media are competing to report on the latest phenomena and social issues in the society to attract public attention and benefit from the news. One of today's social issues in the United States is terrorism, which is often associated with Muslim groups. Recognizing this, we have identified a problem of how the 
media provide information and shape public opinions regarding Muslim groups in the United States. There has been a strong interest in discussing Muslim representation, and the focus of this research is to identify how Muslim groups were portrayed in different media with different political views during the U.S. 2016 presidential election. In addition, it is a very interesting topic for this paper because Muslim representation was one of the hot button issues during the election.

\section{Method}

The four structural frameworks formulated under the framing analysis model proposed by Zhongdang Pan and Gerald Kosicki were used to examine the content of the news. They included syntactical, script, thematic, and rhetorical structures [34]. The analysis was conducted on two large U.S. newspapers, both of which have equal popularity with comparable circulations. The LA Times is the largest daily in the State of California, while the Houston Chronicle is the largest in the State of Texas. In addition, the two are included in the top five states with the largest population in the country. California ranks first with 39.14 million people, while Texas ranks second with 27.47 million people [42]. Thus, the comparison between both media is meant to be a balanced one in terms of population size to which their readers belong.

The first step we took in this research was to choose five articles from each daily using the help of a search engine, Lexis-Nexis. The number was chosen for it was considered sufficient to represent a media perspective of a topic, and the alignments of the two media could be seen clearly through these ten articles. From January 1 to November 8, 2016, the LA Times published 160 articles of different types on Muslim groups, such as main news, hard news, soft news, and opinion. Meanwhile, the Houston Chronicle published 101 articles on the same topic within the same period. However, for this study, we chose to focus on opinion and editorial pieces because they reflected a newspaper's standpoint on an issue.

For the next step, [34] framing model was applied to the collected data in order to dissect the articles' content. In our opinion, framing analysis is the most suitable method to answer the research questions in this paper, which are: Which Muslim groups are featured in the two media that have different political views during the 2016 U.S. presidential election? How are these groups represented in both media? And, does the political affiliation of a media affect the type of news it publishes? In contrast to other theories, the framing theory provides not only a set of variables for a certain phenomenon, such as definition, theorem, and view, but also a methodology through framework structures that greatly helps us analyze data. In addition, the framing analysis sees news as a collection of symbols and codes requiring interpretation, so the validity of information in this method is not measured by objectivity or the researcher's assumption about a news text, but from how the news text stores codes that can be interpreted through the process offered by this analysis method. By using the method, we were able to analyze a news text to determine the direction of the article's alignment by interpreting and unraveling the ideology behind it. 


\section{Result}

The analysis finds that Muslim groups are often generalized as groups coming from the Middle East. Demographically, Muslims in the United States are only a small part of the country's total population. According to [33], the U.S. Muslim population cannot be calculated accurately and officially because the U.S. population census does not ask about religion. However, it is estimated 3.3 million Muslims living in the U.S. or around one percent of the population. The Muslim groups in the United States are quite diverse and generally distinguished by their country of origin, with the Middle East and North Africa occupying the top positions. According to statistics, about 70 percent of the current immigrants in the United States coming from the Middle East and North Africa (MENA) region are Middle Easterners, and the rest are North Africans. Meanwhile, Iraqi immigrants make up the largest population, followed by Egyptians and Lebanese. The number of immigrants from Saudi Arabia and Yemen has also grown tremendously in the last decade [6].

After an in-depth analysis, we observe an attempt by both media to generalize Muslim groups. The Muslim groups depicted in the ten articles from both newspapers are generalized as Middle Eastern Muslims, such as Iraqis and Syrians. In addition, they are typically associated with radical organizations such as ISIS and ISIL, as reported in Houston Chronicle article published on June 15, 2016. In the article, Dionne - the writer - quoted Donald Trump, "We cannot beat ISIL unless we call them "radical Islamists'." ISIL stands for Islamic State of Iraq and Syria. Although the article as a whole does not explicitly mention a certain Muslim group and talks about Muslims in general, the quote adequately illustrates that in media coverage, Muslim groups are often associated with specific organizations.

\section{A great majority of Muslims are peaceful, and it's unfair to blame Islam for terrorist attacks like the one in Orlando. But it is important to hold accountable Gulf state like Saudi Arabia that are wellsprings of religious zealotry, intolerance and fanaticism.}

The above excerpt is taken from Houston Chronicle, "Commentary: Some extremists fire guns; Other extremists promote guns." The two sentences suggest that most Muslims maintain a peaceful attitude, so blaming Islam for terrorism is unfair. However, the author also warned that it was necessary to be cautious of Gulf countries, such as Saudi Arabia, for they were known as the source of religious fanaticism and intolerance. This is the author's framing to emphasize that generalizing Muslims as terrorists is not right, but to say that all Muslims are good is also untrue.

The people who commit these acts are inflamed by a version of an Islamist ideology. They claim an Islamist identity. They swear fealty to organizations like ISIS that govern people according to certain interpretations of the Quran.

From this quote taken from a June 20, 2016 article on the Houston Chronicle, we can see the idea that the author wished to convey that Muslims could not be blamed for the acts of terrorism that occurred in the United States so far. Those responsible were Muslims who had been affected by certain ideologies and misinterpretations of the Quran and joined the ISIS, which had its own agenda. 
The overall message on the LA Times is not much different from the Houston Chronicle. Most of the articles only cover Muslims from the Middle East, as seen in several articles such as "How to add 'Muslim' to 'American"” published on October 28, 2016.

This year's election has been something of a referendum on our faith, on my people. I am the daughter of Syrian immigrants, though unlike the many refugees who are leaving Syria now, my parents came on much more pleasant terms.

The above excerpt is quoted from the LA Times reporting on immigrants from Syria. It speaks of a Syrian American who thought her parents' past immigration was much better than today's Syrian refugee situation. From the statement, it is more likely that the article is talking about Muslim groups from the Middle East than any other Muslim groups.

Another article also making the same kind of generalization is featured on the LA Times with the title "Why Muslims do not need Trump to tell them when to report criminal activity." In the article, the author wrote, "That image is projected on refugees and immigrants communities by violent extremists in the Middle East and xenophobes in the United States, and it is based on a false narrative."

In addition to emphasizing that Muslim groups are from the Middle East, the media are more inclined to divide Muslims into "good" and "bad" Muslims. "Good" Muslims, in this case, can be interpreted as a Muslim civil society that lives a peaceful life, while "bad" Muslims are defined as Muslim individuals who have links to radical organizations, such as ISIS and ISIL, which pose a threat to the national security of the United States.

\subsection{Muslim Representation in the Houston Chronicle}

The Muslims in both media are typically categorized as: (1) Muslims/Islam as a threat; (2) Muslims as victims of discrimination and racism; and (3) Muslims as a dualism. The data analysis of the two dailies finds that Muslim groups were described in a variety of ways during the campaign period. From analyzing the five Houston Chronicle articles, we find two articles framing Muslim groups positively, two describing Muslims neutrally, and one negative article. In contrast, the LA Times was more benevolent to Muslim groups by portraying them in a positive light in their five articles. Building upon the data collected using Pan and Kosicki's framing analysis method, we conclude that Muslims were represented as follows in the two newspapers:

\section{Muslims Displayed as a Threat}

We find one article that paints a negative image of Muslim groups, and this framing can be seen in "Malkin: Not all U.S. Muslim soldiers are equal" published on June 6, 2016 by the Houston Chronicle. It explores the writer's concerns over the allegiance of Muslim soldiers by presenting evidence that in recent years, the country saw a rising number of American Muslim soldiers betraying the United States.

Traitor Hasan Akbar, the 326th Engineer Battalion Muslim-American soldier lobbed stolen hand grenades and shot his M-4 automatic rifle into three tents filled with sleeping commanding officers at the 101st Airborne Division's 1st Brigade operations center in Kuwait in 2003. 
The excerpt above is evidence provided by the writer to reinforce his opinion that Muslim military recruitment could harm the United States. In the sentence, the author emphasized the American attitude towards Muslim soldiers by using the word "traitor".

In another sentence, "A decade later, in 2013, former Muslim-American Navy veteran Abu Khalid Abdul-Latif and an accomplice were convicted of plotting to kill officers and employees at a Seattle military recruiting center," the author gave one more example of American Muslim military betrayal. The use of phrases such as "former Muslim-American Navy Veteran" and "convicted of plotting" can be considered as an attempt to offer real evidence that Islamic liberation within the U.S. military would not be possible because of harm.

Using the framing model of Pan and Kosicki, we are able to dissect the article through its structures, which is very useful to see where exactly the direction of the writer's alignment is. The negative tone adopted by the writer can be clearly seen in the thematic and rhetoric structures. Thematically, he focused on the danger of Muslim soldiers within the U.S. military, which necessitated strict supervision of these military personnel. In the rhetorical element, he used the phrase "not Islamophobic" to convince readers that what he wrote was not based on fear alone but also personal experience. This article vulgarly preaches Muslims and Islam as a threat, which can be seen from the use of negative diction in "killer warriors of God infiltrating our troops and Muslim military menace." Based on analysis, we conclude that this Houston Chronicle article echoes a negative sentiment against Muslim groups in the United States.

\section{Muslims Shown as Victims of Discrimination and Racism}

Out of the five Houston Chronicle articles, two paint Muslims in the United States as victims of discrimination and racism. The framing is evident in "Trump and the GOP's Jurassic Park" published on June 15, 2016. The article outlines the author's opinion that Trump's nomination posed a looming threat to not only the opposition parties but also the entire American society, especially Muslim groups. According to him, the anti-Muslim attitude shown by Trump would put the society in peril as described in his closing, "GOP leaders turned their party into Jurassic Park: They can no more control what they created." Rhetorically, this article reinforces the writer's defense of Muslim immigrants and characterizes Trump as intolerant by incorporating surveys and polls proving that most Americans rejected the policy of Muslim ban from the United States.

Another news report from the Houston Chronicle framing Muslims as victims can be seen in "Mohi: What happened in Orlando was not about Islam." In the article, the author voiced his complaint as a scholar in the United States who wished to challenge the negative assumption about Islam and Muslim groups. He vividly recounted Islam from his side of the story with an emphasis on the title, "What Happened in Orlando was not about Islam". The headline firmly denies Islam's association to violence, especially the terror in Orlando. It also implies that many people thought the Orlando shooting was indeed perpetrated on the basis of faith, which Muslim groups in the United States found troubling.

\section{Muslims Shown as a Dualism ("good Muslims" and "bad Muslims")}

In this sense, a dualism means that Muslims in media coverage fall into two categories: "good Muslims" and "bad Muslims". This dichotomy can be found in "Some extremists fire guns; Other extremists promote guns", where the author tried to direct readers to think that generalizing Muslims as terrorists was unfair, but to say all Muslims were good was also untrue. In this article, we can see he was being neutral towards Muslim groups by neither defending nor attacking them. In this case, he tried to paint a balanced picture, in which the majority of 
Muslims were peaceful, but people needed to remain vigilant, especially against Muslims from areas known to be fanatical and intolerant.

Another article published on June 20, 2016 with the title "Religion's wicked neighbor" also reiterates this dualism. Rhetorically, the author assumed that religion could not be separated from violence, and Islam was no exception. Different and conflicting interests are often responsible for breeding violence. The neutral attitude towards Muslim groups in this article is very clear, in which the author did not attack or use words intended to associate Muslims with certain radical groups, but argued instead that radical groups existed in every religion. Furthermore, he also asserted that people's using religion as a justification for violence happened in all religions. Thus, treating all Muslims as one homogenous entity was simply wrong. One should learn to discern terrorists as terrorists only, as the author said, “...there is the spirit of religion and, frequently accompanying it, its wicked neighbors, the spirit of political and intellectual dominion," confirming that violence arises when religions collude with politics and interests.

\subsection{Muslim Representation in the LA Times}

Our analysis concludes that Muslim groups in the LA Times are represented more positively. We find no article labeling Muslims as a threat. The majority paint an image of Muslims as a minority group and victims of discrimination and racism.

\section{Muslims Displayed as Victims of Discrimination and Racism}

In "Man is accused of hate calls to Islamic center; Police find guns and ammunition at his Agoura Hills home", the author vividly described how Muslims became the victims of antiIslamic bigotry. Thematic structure-wise, the writer emphasized the fears and challenges faced by Muslim groups in the United States. He wrote that in recent times, security forces received numerous reports of hate crimes committed against Muslim groups. Although some considered such hatred as a part of the freedom of expression, when it was manifested in a criminal act that endangered safety, it must be addressed and anticipated.

The next article contributing to framing Muslims as victims is found in "Ignore Cruz and Trump - scapegoating Muslims is an un-American response to the Brussels attacks". We see that through the article, the author tried to evoke sympathy for the Muslim community by saying that what Trump and Cruz said was an attempt to scapegoat Muslims for the attacks in Brussels. The message is highlighted by his use of the word "ignore", which we consider a very strong expression of disapproval of Trump and Cruz's views. He argued that it was not the American way of responding to an act of terrorism.

\section{As the attack in San Bernardino - and 9/11 before it - demonstrated, America is not immune to terrorist attacks. But Muslims in the U.S. are more integrated into the society; where segregation and alienation has played into the hands of terrorist recruiters. Indiscriminate bans on Muslim immigration or "patrols" of Muslim neighborhoods that the Islamic State is propagating.}

The above excerpt is taken from the closing section of the article, which further reinforces the author's message that the negative stigma attached to Muslim groups would only aggravate the situation. He also argued that segregation would create an attitude of "alienation" that allowed terrorists to enter and instill radical doctrine in individuals who felt marginalized from the society. Based on these opinions, we can conclude that this article attempts to frame Muslim 
groups as victims of discrimination and racism, which later becomes evident in the policy of Muslim ban and tight patrol of Muslim neighborhoods.

\section{Muslims Shown as a Dualism ("good Muslims" and "bad Muslims")}

The LA Times shows another example of positive framing by describing Muslims as a dualism. It can be seen in "Why Muslims do not need Trump to tell them when to report criminal activity", which was published on October 14, 2016. It details the author's opinion that the call Trump made in one of his debates was irrelevant. He argued that without being notified, Muslim immigrants in the United States would willingly report any form of criminal activity that put themselves or their neighborhoods in danger, as stated in his writing, "Muslim immigrants have already stepped up as allies to law enforcement," which further stressed that Muslims were being cooperative in upholding the law. He also pointed out that the real threat was not Muslim immigrants but marginalization and negative stigma directed towards the group, which led to an anti-social stance that inhibited information on combating terrorism.

Another LA Times article shedding positive light on Muslim groups was published on October 28, 2016, titled "How to add 'Muslim' to 'America". The author provided a rare glimpse into Muslim representation in the U.S. media, where he talked about an episode from "Peg + Cat" - a children's TV show - telling a story about the festivity and meaning of Eid-alAdha for Muslims. For the writer, the episode felt very important because it represented the acceptance of Muslims in the United States. What made it even better was that the Eid-al-Adha celebration and an image of Muslims as a peaceful community stood out throughout the episode. This is a depiction that is rarely revealed by other major media.

\section{Political Affiliation and Media Alignment}

The political affiliation of a daily newspaper is very influential on their partisanship in an issue. However, based on analysis, we notice that although the Houston Chronicle is on the conservative side of the spectrum, their news coverage of Muslim groups is not vulgarly negative. Of the five articles, only one paints Muslim groups in a negative light. This finding is quite unexpected since we assume conservative media would be more likely to discriminate Muslims by imposing news associating them with radical Islamist groups and branding them potential terrorists who threaten the U.S. national security.

Our analysis shows that the Houston Chronicle is not entirely in favor of Donald Trump, and in some occasions, even challenges him by stating that his remarks and policies are unconstitutional. In several articles, some authors tried to suggest that Muslim groups in the United States were victimized by Trump's generalization, which would eventually undermine the unity and endanger the country. We see that despite being known as a conservative daily, the Houston Chronicle seems to be trying to create a balanced representation of Muslim grouprelated issues on the news. It is evident in the variety of ways Muslims are described in their news coverage without ever cornering the group. In brief, while political affiliation plays a major role in determining the way the media describes an issue, the coverage of Muslim groups is actually very complex.

In the LA Times, on the other hand, the news coverage of Muslim groups in the United States during the presidential campaign is framed in a less varied manner by simply adopting a positive tone. Through some of the articles, the authors tried to convey that the generalization of Muslim community was unfair. It was correct to say that there were some "bad apples", but it was simply wrong to characterize all Muslims as terrorists. It can be said that this assertion of opinion is in line with the liberal view of freedom and equal rights - highlighting that Muslim 
groups in the United States are no different from other groups. They have the same rights to be treated like anyone else.

\section{Conclusion}

This paper argues that although it is not the sole determinant of media alignment, the political affiliation of a media is quite influential on the way it covers an issue. In the Houston Chronicle articles, Muslim groups in the United States are branded in a more diverse way. Two articles frame Muslim groups as victims of anti-Islamic sentiments; two frame Muslim groups as a form of dualism; and one vulgarly reports Muslims as a threat to the United States. The $L A$ Times, on the other hand, represents Muslim groups as a form of dualism and victims of discrimination and racism. This daily strongly challenges the generalization of Muslim groups as terrorists by pointing out that Muslims in the United States are faced with many adversities, such as hate crimes, caused by negative sentiments or anti-Muslim attitudes. In some of the articles, the LA Times tries to get the message across that certain actions of the U.S. Government coupled with some of Trump's statements cornering Muslim groups in the United States may cause new and more serious problems. Given the negative sentiments, Muslim groups would be more likely to withdraw from the society and create a narrow nationalist sense within the community. This would be an entryway for terrorist groups to recruit individuals to join their radical acts. The emphasis on the concept of dualism is strongly echoed by the LA Times as they try to clearly distinguish Muslims from terrorists.

Based on analysis, this paper concludes that media coverage of an issue is very complex. Many aspects come into play in determining the alignment of a media, one of which is political affiliation. Although it is not necessarily a major factor, political affiliation serves as a basis for how the media express opinions. In addition, we also conclude that the political view of a media is never simplistic. A media with a conservative political affiliation is not always fully supportive of the Republican presidential candidates. Some articles in conservative newspapers strongly disagree with Trump's statements about Muslims, with the argument that generalizing Muslims as members of radical groups is uncalled-for.

Although this paper provides a picture of media framing of Muslim groups in the United States and how political affiliation affects the news, it does not include a broader description of how the media influence Muslim groups since further research involving readers is needed for this purpose. Subsequent research can use or add quantitative methods by including surveys to see whether the media are attributable to the emergence of Islamophobic attitudes. In addition, increasing the quantity of corpuses would further enrich the research into Muslim groups in the United States.

In the process of preparing this paper, we come to a conclusion that media coverage has a significant role in shaping readers' opinions. How much news consumed and how the news is presented greatly affect the readers in perceiving the covered issues. Therefore, it would be wise for readers, whatever their political affiliation is, to be more "news literate" by digging information from multiple sources before forming their personal opinion on an issue and not to be carried away by the perspective or ideology of the media. 


\section{References}

[1] Abu-Ras, Wahiba M., and Zulema E. Suarez. (2009). Muslim men and women's perception of discrimination, hate crimes, and PTSD symptoms post 9/11. Traumatology 15.3: 48-63. Http://journals.sagepub.com/doi/abs/10.1177/1534765609342281.

[2] Ahmed, Sara J. (2007). Evaluating the "New York Times"” Framing of Islam and Muslims Pre- and Post-9/11. (Doctoral dissertation). Order No. 1443827 University of Houston, Ann ArborProQuest. 3 Apr. 2017 http://search.proquest.com/docview/228166597?accountid=1726841

[3] Alsultany, E. (2013). Arabs and Muslims in the media after 9/11: Representational strategies for a "postrace" era. American Quarterly, 65(1), 161-169,261. Retrieved from http://search.proquest.com/docview/1409095975?accountid=17268

[4] Aydin, C. \& Hammer, J. (2010). Muslims and media: Perceptions, participation, and change, 4(1), 1-9. Retrieved from doi:http://dx.doi.org/10. Contemporary Islam 1007/s11562-009-0098-7

[5] Banks, J.A. \& Banks, C.A. (2003). Multicultural education: Issues and perspectives (4th ed.). New York, NY: John Wiley \& Sons, Inc.

[6] Batalova, Jeanne, and Jie Zong. (2017). Middle Eastern and North African Immigrants in the United States. Migrationpolicy.org. Web. 2 May 2017. Retrieved from http://www.migrationpolicy.org/article/middle-eastern-and-north-african-immigrants-united-states

[7] Benford, Robert D., and David A. Snow. (2000). Framing Processes and Social Movements: An Overview and Assessment. Annual Review of Sociology. 26: 611-39. Retrieved from https://www.jstor.org/stable/223459

[8] Bogdan, R.C. \& Biklen, S.K. (1982). Qualitative research for education: An Introduction to theory and methods. Boston: Allyn and Bacon, Inc.

[9] Bogdan, R., Taylor, S. (1987). Looking at the bright side: A positive approach to qualitative policy and evaluation research. Qualitative Sociology. 13 (2): 183-192. doi:10.1007/BF00989686

[10] Bowe, B. J., Fahmy, S., \& Matthes, J. (2015). U.S. newspapers provide nuanced picture of Islam. Newspaper Research Journal, 36(1), 42-57. 2015. Retrieved from doi:http://dx.doi.org/10.1177/0739532915580312

[11] Buehler, A. F. (2011). Islamophobia: A Projection of the West's 'Dark Side'. Islam and Civilisational Renewal, 2(4), 639-653,765-766. Retrieved from http://search.proquest.com/docview/1315158997?accountid=172684

[12] Burton, Graeme. (2005). Media and Society: Critical Perspectives. Universitas Michigan. Open University Press, Web. 4 Apr.2017. Retrieved from https://books.google.co.id/books/GraemeBurton/representation

[13] Butler, Taryn. (2005). The media construction of terrorism pre and post 9/11. McKandree

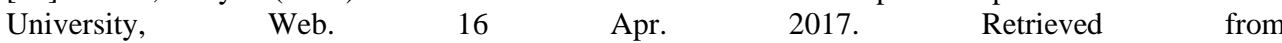
https://www.mckendree.edu/academics/scholars/butler-issue-24.pdf

[15] Cappella, J. N. \& Jamieson K. H. (1996). News frames, political cynicism, and media cynicism, The ANNALS of the American Academy of Political and Social Science, 546, 71-84

[16] Chermak, S. M. \& Gruenewald, J. The media's coverage of domestic terrorism. Justice Quarterly: JQ, 23(4), 428-461. 2006. Retrieved from AlKahtani, Ali Abdullah. The Post-September 11 Portrayal of Arabs, Islam and Muslims in "The Washington Post" and "The New York Times": A Comparative Content Analysis Study. Order No. 3085562 Howard University, 2002 Ann ArborProQuest. 30 Mar. 2017 .

[17] Creswell, J. W. (2008). Educational Research: Planning, conducting, and evaluating quantitative and qualitative research (3rd ed.). Upper Saddle River: Pearson.

[18] Defining Islamophobia. (n.d). Center for Race \& Gender. University of California, Berkeley.Web. 13 Apr. 2017. Retrieved from http://crg.berkeley.edu/content/islamophobia/defining-islamophobia

[19] Gallup, Inc. (2017). Islamophobia: Understanding Anti-Muslim Sentiment in the West. Gallup. Web. 23 Mar. 2017. Retrieved from http://www.gallup.com/poll/157082/islamophobia-understandinganti-muslim-sentiment-west.aspx

[20] Ghazali, Abdus Sattar. (2004). Muslim Immigration to the USA. American Muslim Perspective. Web. 14 Apr. 2017. Retrieved from http://www.amp.ghazali.net/html/four_waves.html 
[21] Goffman, E. (1974). Frame analysis: An essay on the organization of experience. Cambridge. Mass: Harvard University Press.

[22] Habib, Samra. (2016). Islamophobia is on the rise in the US But so is Islam. Web. 18 June. 2017. Retrieved from https://www.pri.org/stories/2016-09-09/muslims-america-are-keeping-and-growingfaith-even-though-haters-tell-them-not

[23] Haddad, Yvonne Yazbeck. (1986). A century of Islam in America. Washington, D.C.: American Institute for Islamic Affairs, Print.

[24] Handbook of Texas Online. (n.d). Houston Chronicle. Web. April 26, 2017, http://www.tshaonline.org/handbook/online/articles/eeh02.

[25] History LA Times. (n.d). Los Angeles Times. Los Angeles Times. Web. 16 Apr. 2017. Retrieved from http://www.latimes.com/la-mediacenter-history-story.html

[26] History Times: A Nation of Immigrants. The Gilder Lehrman Institute of American History. (2012). Web. 20 Mar. 2017. Retrieved from https://www.gilderlehrman.org/history-byera/immigration-and-migration/essays/history-times-nation-immigrants

[27] Kennedy, John F. Kennedy, Robert F.(1964). A Nation of Immigrants. HarperCollins. 1964.

[28] Kothari, C. R. (2008). Research Methodology, Methods and Techniques (2nd ed., pp. 109-110). New Delhi: New Age Inter- national (P) Limited.

[29] Leonard, K. I. (2003). Muslims in the United States: The State of Research. New York: Russell Sage Foundation. Project MUSE. Retrieved from https://www.russellsage.org/sites/default/files/leonard_chapter1_pdf.pdf

[30] McQuail, D. (2010). McQuail's mass communication theory. London: Sage Publications.

[31] Miller, K. (2000) Communication Theories: Perspective, Processes and Context. Boston: McGraw Hill, 2000.

[32] Mohamed, Rasha. (2007). Where are the Real Arabs and Muslims? A Content Analysis of the Portrayals of Arabs and Muslims in Online Print and Video News Reports. Order No. 1451010 California State University, Fresno. Ann ArborProQuest. 30 Mar. 2017.

[33] Mohamed, Besheer. (2016). A new estimate of the U.S. Muslim population. Pew Research Center. N.p. Web. 23 Apr. 2017. Retrieved from http://www.pewresearch.org/fact-tank/2016/01/06/a-newestimate-of-the-u-s-muslim-population/

[34] Pan, Z. \& Kosicki, G. (1993). Framing analysis: An approach to news discourse. Political Communication, 10(1), 55-75. doi:10.1080/10584609.1993.9962963

[35] Said, Edward W. (1997). Covering Islam: How the Media and the Experts Determine How We See the Rest of the World, Vintage Books, New York,

[36] Schutt, Russell K. (2006). Investigating the Social World: The Process and Practice of Research, 5th ed. Thousand Oaks, CA: SAGE/Pine Forge Press.

[37] Shah, D. V., McLeod, D. M., Gotlieb, M. R., \& Lee, N. J. (2009). Framing and agenda setting. In R. L. Nabi \& M. B. Oliver (Eds.), Media processes and effects (pp. 83-98). Thousand Oaks, CA: Sage. [38] Smith, Jane I. (n.d). Patterns of Muslim Immigration. Office of International Information Programs. U.S. Department of State. Retrieved from http://www.4uth.gov.ua/usa/english/society/muslimlife/immigrat.htm

[39] Snow, David A., E. Burke Rochford, Jr., Steven K. Worden, and Robert D. Benford. (1986). "Frame Alignment Processes, Micromobilization, and Movement Participation." American Sociological Review 51(4): 464-81

[40] Stuart, Hall. (1997). Representation: Cultural Representation and Signifying Practices. SAGE publication. Web. $6017 . \quad$ Apr. $\quad 2017$ Retrieved from https://faculty.washington.edu/pembina/all_articles/Hall1997.pdf

[41] Thesamhita. (2016). Islamophobia in America is worse on 9/11/2016 than it was on 9/11/2001. Mic. Mic Network Inc. 13 Mar. 2017. Retrieved from https://mic.com/articles/153864/islamophobiain-america-is-worse-on-9-11-2016-than-it-was-on-9-11-2001\#.kEYDVR0Ox

[42] U.S. Census Bureau. (2015). North Carolina Becomes Ninth State With 10 Million or More People, Census Bureau Reports. Retrieved from https://www.census.gov/newsroom/press-releases/2015/cb15215.html 
[43] Yusuf, Hassan, et al. (2013). The Framing of International Media on Islam and Terrorism. European Scientific Journal edition vol.9, No.8. We See the Rest of the World. (1997). Vintage Books, New York. 